\title{
Changing Attitudes towards Assisted Reproduction and IVF
}

\author{
Kelly Oliver* \\ Distinguished Professor of Philosophy, Vanderbilt University, USA
}

Submission: July 17, 2017; Published: August 21, 2017

*Corresponding author: Kelly Oliver, Distinguished Professor of Philosophy, Vanderbilt University, USA; Email: kelly.oliver@vanderbilt.edu

\section{Opinion}

If not so long ago pregnancy was something to be hidden, a private matter that required modesty in dress and behavior, now with sexy pregnant bodies and protruding baby bumps on the covers of tabloids every week, a new stigma is attached to Assisted Reproductive Technologies (ART), In Vitro Fertilization (IVF) and what goes on at fertility clinics, which is often showed in secrets. If a few decades ago a woman's pregnant body was considered obscene insofar as it was associated with sex-it was proof that she had sex--today the disconnect between sex and pregnancy made possible by new reproductive technologies appears as the new obscenity. Medical intervention into socalled "natural" reproduction and "good old fashioned" heterosex is represented as suspect, even gross. And women who use these new technologies are pictured as unnatural-when they are seen at all. Even while popular culture celebrates celebrity pregnancies, tabloids also vilify women such as Kate Gosselin and Nadya Suleman (Octomom) who use ART to have multiple infants. Women who have multiple babies are pictured as excessive, even monstrous, and yet we can't get enough of them. Without sex, in popular media, pregnancy appears in as horrifying, comic, or both.

Recent ART films (artificial reproductive technology films) such as The Brothers Solomon, Baby Mama, The Back Up Plan, and The Switch, present artificial reproductive technologies as both gross and funny. In most of these films, ART is an obstacle to overcome for the sake of romance and love. If, in earlier romantic comedies, class and cultural differences were obstacles to romance that created tensions to be resolved by the end of the film, here chemistry-literally-- is the obstacle that has to be resolved by the natural chemistry between characters. In these films, the couple is united in the end through the adventures and mishaps of ARTs and "artificial" pregnancies, which are replaced by "old fashioned" natural sexual reproduction. Real reproduction and real babies replace the artificial ones.

For example, in Baby Mama, surrogate Angie's IVF pregnancy really is a fake that doesn't take; and by the end of the film peri- menopausal Kate and her new boyfriend celebrate the unlikely event of real pregnancy. To great comic effect, in Baby Mama and Labor Pains fake pregnant women imitate and parody stereotypes about pregnancy, from food cravings to morning sickness. And both Baby Mama's Angie and Labor Pain's Thea (Lindsay Lohan) stuff, shift, and grab their prosthetic bellies with abandon in funny scenes that make pregnancy detachable, an accessory to be worn and then removed-as the tabloids tell us: get "rid of that baby fat" and get your "real body" back. In the end, however, both Angie and Thea really do get pregnant. Fake pregnancies give way to real ones.

Baby Mama, along with Juno and its more recent sisters The Back Up Plan and The Switch can be seen as warnings to young women to have babies while they still can, with or without male life-partners. They serve as cautionary tales for career women who have waited too long and are now suffering from what Sylvia Ann Hewlett, in her controversial book, calls "baby hunger." In all of these films, career women take matters into their own hands in response to biological clocks set to go off like timebombs that end their fertility. Of course, since these films are romantic comedies, they always end up with male partners, and their babies are the products of romance. Even in The Back Up Plan, after Zoe (Jennifer Lopez) has twins as a result of artificial insemination, the film ends with her pregnant by her new lover Stan (Alex O'Loughlin) with a more romantic "real" baby. The film seems to warn, if she had only waited one more day before resorting to IVF, she could have had a real family with all her babies biologically related to their new dad. Interestingly, the way that Stan finally proves his love to Zoe is by accepting her redheaded IVF babies as his own.

"Who's your daddy now" takes on new meaning in an age when sperm banks are big business and donor's identities are usually confidential. And with egg donation taking off, the identity of biological mothers is not as certain as it once was. In fact, genetic engineering makes it possible to use genetic material from two or more women's eggs, which can then be implanted 
into another's woman's womb (the "gestational carrier"), who can carry the fetus for yet another woman. This means, it is now possible to have three or more biological mothers. And, thanks to IVF, those mothers can be older. For example, ten years ago, a 67-year old woman gave birth to twins.

In the U.S., there is very little regulation of IVF, and sperm and egg donation. Egg donors, especially college educated women, can make $\$ 30,000-\$ 50,000$. And sperm donation is a billion dollar business. Every year the number of women using IVF or ART increases. And yet, much of this industry is shrouded in secrecy. Unlike Canada, or other countries, there is no limit on the number of embryos that can be implanted; and usually several embryos are implanted to make sure one of them "takes." This means doctors use what they call "selective reduction" (abortion) to remove some of the embryos for women who don't want multiple births. ART and IVF open up new options to women, but at the same time, they bring new difficulties and tribulations, including expensive medical procedures, side effects from hormones, multiple implantations, and selective reduction. Reproductive technology is outstripping ethical and legal deliberations over the effects of ART and IVF on women's health and women's lives.

\section{Author Biography}

Kelly Oliver is Distinguished Professor of Philosophy at Vanderbilt University and well-known feminist philosopher. She is the author of fourteen nonfiction books, most recently, Hunting Girls: Sexual Violence from The Hunger Games to Rape on Campus, which won a 2016 Choice Magazine award, and Knock me up, Knock me down: Images of Pregnancy in Hollywood Film. Her new mystery trilogy takes on ripped-fromthe-headlines crimes like rape drugs on campus, sex trafficking, and the secretive world of IVF. The adventure begins with Wolf: A Jessica James Mystery, followed by Coyote: A Jessica James Mystery, and most recently F.O.X.: A Jessica James Mystery, which highlights problems around ART and IVF. Learn more the Jessica James Mysteriesand Kelly Oliver's other books at www. kellyoliverbooks.com

\section{Your next submission with Juniper Publishers} will reach you the below assets

- Quality Editorial service

- Swift Peer Review

- Reprints availability

- E-prints Service

- Manuscript Podcast for convenient understanding

- Global attainment for your research

- Manuscript accessibility in different formats

( Pdf, E-pub, Full Text, Audio)

- Unceasing customer service

Track the below URL for one-step submission https://juniperpublishers.com/online-submission.php 